have always found it rather difficult to prove to a student that the Lower and Upper Carboniferous beds really belong to one formation at all, so great is the contrast between the "essentially" marine aspect of the Iower, and the essentially lacustrine aspect of the upper division. If this be so, is it not "philosophical" to suppose that there is a middle group, between these extremes, "essentially" marine, yet less oceanic than the lower stage of the Mountain Limestone?

Meanwhile, allow me to ask my colleague to defer his opinion on the views I have stated in my paper till he has had an opportunity of reading it.

EDw.ARD HoLl.

Geologicat Surver op Irelaxd, Office, 14, Hume-street, Dublin.

\title{
THE RELATION OF THE PERMIAN TO THE TRIAS.
}

Sir,-Mr. Irving appears to have quite mistaken the purport of my communication on the relation of the Permian to the Trias in the neighbourhood of Nottingham. I understood it had been stated by geologists of Nottingham, that not only a perfect conformity existed between the Permian and the New Red Sandstone near that town, but there was a passage upwards from one formation into the other.

I merely wrote to say this could not be, for the reasons I gave. But I never intended to imply there was not a general conformity between the two formations, for this general conformity must be apparent to any one on looking at a good geological map, whereon these formations are laid down. Neither did I intond it to be understood that I considered that the break between the Permian and the New Red Sandstone was greater than between some of the subdivisions of these formations. As, for instance, the break between the Middle Marls and Lower Magnesian Limestone of the Permian, or that between the Keuper and the Bunter of the Trias. I gave no opinion one way or the other on these points.

The point of my communication was this. The relation of the Permian to the Trias I considered an important problem yet to be worked out. If a perfect passage from the one up into the other was found, it would go far to settle the question. As far as I know, that passage has not been found, and, I contend, it does not exist in the neighbourhood of Nottingham.

Some personal remarks in Mr. Irving's communication I shall not reply to, they have nothing to do with the question, and were wholly uncalled for. I do not consider the pages of a scientific magazine the place for that kind of bantering.

W. TALBot AVEline.

\section{HURONIAN VOLCANIC ROCKS.}

SrR,-In an able paper in your last issue, Mr. George M. Dawson publishes the results of his study of the "Porphyrite Formation" of British Columbia, and applies these results to the explanation of the origin of the Huronian series of Eastern. North America. I an particularly pleased to find so good an observer as Mr. Dawson not

1 Geou. Mag. Dec. II. Vol. IV. p. 155. 
only prepared to affirm that the Huronian rocks on the Lake of the Woods are in great part volcanic, but putting forward the theory that the Huronian formation is largely composed of metamorphosed contemporaneous igneous matter. This is the view to which I was myself led by my study of these rocks in the field, and I published this opinion in a paper on the Geology of the North Shore of Lake Superior some years ago (Quart. Journ. Geol. Soc. vol. xxix.). In this paper I expressed the opinion that the great masses of "talcose" and "chloritic" slates which, together with interbedded traps, make up the greater part of the Huronian formation between Lake Superior and Lake Shabendowan, are " truly of the nature of bedded felspathic ashes;" and I also drew attention to the singular resemblance which they present to the Borrowdale series, or Green Slates and Porphyries, of the North of England. It affords me, therefore, much pleasure to find that these views, at that time quite unsupported, should have been corroborated by the wide opportunities for observation and the extended experience of Mr. Dawson.

Uyited College, St. Andrews, H. Alleyne Nicholson. July $7 t h, 1877$.

\section{OBITUARY. \\ WILLIAM HARRIS, ESQ., F.G.S. \\ BORx 1797. DIED $187 \%$.}

With regret we announce the death of WrLLIAM Harris, Esq., F.G.S., on the 13th May, aged 80, at Charing, in Kent, where he had resided for many years. He was greatly esteemed by a large circle of friends for his genial disposition and real philanthropy; and he obtained deserved reputation for his untiring researches among the fossils of the Chalk, and into the geological history and structure of the country around him. He was elected a Fellow of the Geological Society of London in 1839. After a long life of useful activity bis health failed bim eight or nine years ago, and he gradually lost his power of moving about and attending to business, as well as his interest in those scientific pursuits which were formerly his pleasure. He had for many years assiduously collected the organic remains found in the Chalk-pits of the neighbouring hills, especially the Sponges and Fishes. Of the former he communicated many to Mr. J. Toulmin Smith, who figured and described the Ventriculide of the Chalk in 1848. Of the Fishes he collected and prepared a great many, but they were never classified. The enormous numbers of Entomostraca, Polyzoa, and Foraminifera, together with small Brachiopods, Serpula, fragments of Corals, Encrinites, etc., which Mr. Harris obtained, by careful and patient search, from the Chalk and Chalk-marl, were freely and liberally distributed to his friends, and to others interested in palæontology. Many a one has been instigated to take up geological studies, with microscope at home and hammer abroad, after participating in some of these minute organic treasures from " the Charing Detritus," as the disintegrated Chalk-marl of the locality was termed by our lamented frieud. 